\title{
SERVICES FOR LEARNING DISABLED ADOLESCENTS:
} A SURVEY

This article presents the results of a nationwide survey conducted to determine the types and availability of services being provided to learning disabled $\mathbf{R}$ adolescents. Results are summarized under three main categories: procedures, services for learning disabled adolescents, and problems and needs. As a consequence of PL 94-142, public schools are moving to comply with the law; thus, much of the data in this survey must continually be updated and reanalyzed. D.D.D.

The basic purpose of this survey was to estimate the availability and types of special services currently provided to specific learning disabled (SLD) adolescents. Questionnaires were mailed to 301 randomly selected local education agencies (LEAs) across the nation. Specifically, information was gathered concerning the procedures used to identify and place SLD students at the secondary level, the current availability and range of services for SLD adolescents, and the primary problems LEAs face when serving these students.

When comparing percentages for demographic variables of the sample to national distribution, the sample appears to be representative of the nation with regard to locality of residences, socioeconomic levels, and racial composition. However, since this study was designed to provide a general picture of current services, statistical efficiency was not the primary intent and, thus, the results should not be construed to be accurate for any one state or section of the nation.

\section{Results}

Identification procedures. As expected, terminology referring to SLD students differed widely. "Learning disabilities" and "specific learning disabilities" were the most widely used terms with $57 \%$ of the respondents reporting the use of these labels. Variations of these terms (e.g., "special learning disabilities" or "learning disorders") as well as a variety of other terms (e.g., "educationally handicapped," "children with exceptional needs," "perceptually handicapped") were also identified.

Consistency in the identification process was noted only in that a predominant propor-

GAYE McNUTT, Ph.D., is Area Coordinator of Special Education, University of Oklahoma.

GINGER HELLER is a doctoral student in Special Education at the University of Georgia. 
tion of the LEAs required the use of intelligence tests and achievement tests $(97 \%$ and $87.4 \%$, respectively). Slightly over $50 \%$ of the respondents required hearing and eye examinations. It is interesting to note that only $4.6 \%$ of the respondents required observation of the student. In light of the new SLD regulations, it is highly likely that these identification procedures will be rapidly changing.

The percentage of students identified as SLD ranged from less than $1 \%$ to $20 \%$ of the enrollment of the high schools which responded. However, $67.5 \%$ of the districts estimated the rate to be $3 \%$ or less.

Services for SLD adolescents. Of the questionnaires returned, $22.5 \%$ responded that there were no programs for SLD students attending high school. This percentage would be higher if it included the LEAs which indicated that while SLD services were available, vocational education was the only "special" service offered. Of those districts providing services, $65 \%$ indicated that their program(s) had been available for three years or less; $25 \%$ had been in existence for only a year or less; $10 \%$ of the programs had been available for seven or more years.

The resource room was the most popular model for serving identified SLD students. As depicted in Table 1, various combinations of resource, integrated, and self-contained programs were also offered. Approximately $86 \%$ of those having programs indicated that work study and/or vocational education programs were available to SLD students in addition to special education services. However, just over $10 \%$ indicated that one or both of these programs were open to regular education students but not to those identified as SLD.

Within the resource room setting, the curriculum areas of reading, math, language arts, and social studies were most frequently mentioned as subjects in which the SLD students received assistance. Most respondents indicated that, rather than assuming full responsibility for them, the teacher usually helped students with these areas as they related to the students' regular education courses. Counseling and affective education programs were provided as part of the resource room services in over half of the cases. Finally, resource teachers served as consultants to regular education teachers in $87.7 \%$ of the LEAs responding to this question.

Problems and needs. A predominant number of the respondents indicated that regular education personnel's lack of understanding of the purposes of special services for SLD adolescents was a major stumbling block in providing effective programming.

Table 1

Special Services Offered to High School LD Students

\begin{tabular}{lc}
\hline Service Arrangement & $\begin{array}{c}\text { Percent of Districts } \\
\text { Offering the Service }\end{array}$ \\
\hline Resource room only & 51.2 \\
Resource room and integrated class & 25.6 \\
Resource room/integrated/self-contained class & 12.2 \\
Resource room and self-contained class & 1.2 \\
Integrated class only & 2.5 \\
Self-contained class only & 1.2 \\
Work study and/or vocational education only & 6.1 \\
\hline
\end{tabular}


Problems relating to funding (e.g., the lack of adequate facilities and appropriate materials) ranked second as a major problem.

The most commonly identified need was related to providing appropriate vocational and career education programs for SLD students. Closely related to this and to the problem of communication between regular and special education personnel was the frequently expressed need for making adjustments in the high school curricula to provide flexible and effective programs for SLD students.

\section{Discussion}

Based on the information gathered from the returned questionnaires, several problems appear to be prominent. First, some LEAs offer no special services to SLD adolescents. Second, many of the LEAs that do provide special services offer a limited range of services or alternatives. Third, identification procedures suffer from a lack of consistency. And, fourth, there appears to be a need for increased communication and understanding between special and regular educators.

It is the authors' belief that recent Federal legislation (e.g., PL 94-142 and the accompanying SLD regulations) will ameliorate the first and third problems if educators insist that such mandates be fulfilled. Federal legislation may also be useful in solving the problem of limited alternatives for SLD adolescents. However, parents and educators may have to work together to insist that LEAs provide a wide range of alternatives for SLD adolescents. Related to the fourth problem, special educators will likely be assuming the responsibility for increasing communication and understanding between special and regular educators. If this is the case, it appears that we will need not only to be teachers and consultants, but also public-relations specialists.

Finally, while this survey did not consider the quality or effectiveness of programs, these variables should be the focus of future investigations. Both new and established programs need to be scrutinized to determine if they are effective in preparing SLD adolescents to function competently in society. If programs cannot validate their effectiveness, serious questions should be raised concerning whether or not they should be maintained. 


\section{REFERENCES}

American Psychiatric Assn.: The diagnostic and statistical manual of mental disorders (2nd ed.). Washington, D.C.: APA, 1968.

Birch, $H$. Dyslexia and the maturation of visual function. In J. Money (Ed.), Reading disability. Progress and research needs in dyslexia. Baltimore: Johns Hopkins Press, 1962.

Birch, $\mathrm{H}$. Some ways of viewing studies in behavioral development. Modern Problems in Pediatrics, 1974, 13, 320-329.

Brunner, J., \& Starkey, J. Interpersonal relationships and the self concept. Unpublished paper, Northern Illinois University, DeKalb, Illinois, 1974. (ED 089-515)

Cohen, J., \& Cohen, P. Applied multiple regression/correlation analysis for the behavioral sciences. Hillsdale, N.J.: Lawrence Erlbaum Associates, 1975.

Critchley, M. Developmental dyslexia. London: Wm. Heinemann, Ltd., 1964.

deHirsch, K. Two categories of learning difficulties in adolescents. American Journal of Orthopsychiatry, 1963, 33, 87-91.

Denckla, M. Research needs in learning disabilities: A neurologist's point of view. Journal of Learning Disabilities, 1973, 6, (10), 441-450.

Evans, H. Remedial reading in secondary schools still a matter of faith. Journal of Reading, 1972, 16, 111-114.

Goodman, L., \& Mann, L. Learning disabilities in the secondary school, issues and practices. New York: Grune and Stratton, 1976.

Gottesman, R., Belmont, I., \& Kaminer, R. Admission and follow-up status of reading disabled children referred to a medical clinic. Journal of Learning Disabilities, 1975, 8, (10), 642-650.

Hollingshead, A., \& Redlich, F. Social class and mental illness: A community study. New York: John Wiley, 1958.

Jastak, J., \& Jastak, S. The Wide Range Achievement Test. Wilmington, Delaware: Guidance Associates of Delaware, Inc. 1976.

Karlsen, B., Madden, R., \& Gardner, E. Adult Basic Learning Examination. New York: Harcourt, Brace, Jovanovich, Inc., 1970.

Kenny, T., Clemmens, R., Cicci, R., Lentz, G., Prasanna, N., \& Hudson, B. The medical evalu- ation of children with reading problems (dyslexia). Pediatrics, 1972, 3, 438-442.

Koppitz, E. Children with learning disabilities: A five-year follow-up study. New York: Grune \& Stratton, 1971.

Kronick, D. Guidelines for parents. In L. Anderson (Ed.), Helping the adolescent with the hidden handicap. Los Angeles: California Association for Neurologically Handicapped Children, 1970.

Kronick, D. What about me? The LD adolescent. San Rafael, California: Academic Therapy Publications, 1975.

Mazurkiewicz, A. New perspectives in reading instruction (2nd ed.). New York: Pitman Publishing Corp., 1968.

Muehl, S., \& Forrell, E. A follow-up study of disabled readers: Variables related to high school reading performance. Reading Research Quarterly, 1973-74, 1, 110-123.

Roswell, F., \& Natchez, G. Reading disability, a human approach to learning (3rd ed.). New York: Basic Books, Inc., 1977.

Rutter, M., Tizard, J., \& Whitmore, K. A neuropsychiatric study in childhood. Clinics in Developmental Medicine, Nos. 35/36. Philadelphia: J.B. Lippincott, 1970.

Rourke, B., Orr, R., \& Ridgley, B. Neuropsychological abilities of normal and retarded readers: $A$ three year follow-up. Presented at the meeting of the Canadian Psychological Association, Windsor, 1974.

Shepherd, M. Learning disabled or slow learner? Teacher, 1975, March, 29-31.

Silberberg, N., \& Silberberg, M. The bookless curriculum: An educational alternative. Journal of Learning Disabilities, 1969, 2, (6), 302-307.

\section{FOOTNOTES}

'This study was supported in part by the Department of Health, Education and Welfare's Maternal and Child Health Project 241, Training in the Care of the Handicapped Child.

${ }^{2}$ As stated in Centerfold November, 1976, Newsletter of the Title VI-G Network of Child Service Demonstration Centers, funded by Bureau of Education for the Handicapped, U.S. Office of Education.

\section{CORRECTION}

In $L D Q$, Vol. 1, No. 4, Fall, 1978, an error was made in reporting the author information of the article entitled the EFFECTS OF SYNTACTIC COMPLEXITY UPON ARITHMETIC PERFORMANCE.
The order of contributing authors should read as follows:

Barbara Trenholme, Steve C. Larsen, and Randall Parker. - D.D.D. 